silvery pollinose. Pair of median stripes hardly apparent, and only on third segment. No black on legs or antennae. Otherwise agrees with Williston's description.

The common form of this species in New Mexico, especially in the Mesilla Valley, is the present one - that originally described by Say as abdominale. It is characterized in general by the front, median abdominal stripes, and legs being as described above. The thorax has the median brown line less conspicuous, or subobsolete; the abdomen with at least second and sixth segments mostly yellowish; abdomen sometimes wholly yellowish, in which case the median stripes may be moder- ately distinct but reddish. See section II of paper on Gila Diptera (Psyche, I 897), for note on fulvifrons, typical form.

4. Belvosia bifasciata Fab. One q. Dripping Spring, Organ Mts. About 5600 ft. August ro. Not quite the normal type, but near it. Facial ridges ciliate half way up, but not as high as lowest frontal bristles. Third antennal joint about $2 \frac{1}{2}$ times as long as second. Third and fourth abdominal segments wholly deep golden, as in the normal form. The claws in $q$ of this genus are always hooked and black on tips. The $\delta$ has the claws nearly straight, and without black.

\title{
LIFE HISTORY OF PYROMORPHA DIMIDIATA H. S.
}

\section{BY HARRISON G. DYAR, WASHINGTON, D. C.}

The larva of Pyromorpha has previously eluded detection on account of its peculiar habit. It lives beneath the fallen leaves in oak woods, feeding on the dead and decaying leaves. The larvae are solitary. The period from egg to cocoon is three months, June ${ }_{1} 5$ to Sept. 15. The winter is passed in the cocoon as in the other species of the family. The coloration is dark brown and rather uniform to harmonize with the situation in which the larvae live.

$E g g$. Elliptical, a little flattened above and below like Geometrid eggs, but more elongate and cylindrical than those. White, moderately shining, soft and thin-skinned. Length I mm., height and width $.6 \mathrm{~mm}$. Reticulations distinct and regular, much rounded, like a series of contiguous circles.

Stage I. Head rounded, partly retracted, black; width $.3 \mathrm{~mm}$. Body thick, slightly flattened, grayish white. Warts low, a group of hairs from tubercular bases, finely dotted spinulose, a small clear bulb at the base of each. Three warts and leg-plate seen, the larva wart with few hairs. Skin finely spinulose. The primitive first stage is absent.

Stage II. Head retracted in the fold of joint 2 , black over the vertices of the lobes, clypeus pale, mouth pointed, brown; width $.4 \mathrm{~mm}$. Body sordid gray, in marks. Hairs numerous, from large low warts, stiff, shut, pale with black tips, spinulose with basal bulbs as before. Feet normal. Later a faint whitish subdorsal line is seen against the dark fold within, a narrow brown dorsal line and faint mottlings low down on the sides. Cervical shield brown.

Stage III. Head light brown with large black eye, retracted in joint 2 ; width $.6 \mathrm{~mm}$. Body thick and stout, densely hairy. Cervi- 
cal shield large, exposed, dark brown and nearly naked. Color grayish like dead leaves, a narrow, dark brown dorsal line. Warts low, flat, but large in three rows. Hairs rather pale, but in general concolorous, stiff, sharp-pointed with clear basal bulbs. Under a high power the spinules are seen to form equidistant rings making the hair appear segmented. Skin densely minutely spinulose. The large pale warts give the appearance of broad, faintly paler subdorsal and lateral bands, separated by the straight dorsal and broken lateral brown lines which gradually become defined.

Stage $I V$. Head light brown, eye black; width $.8 \mathrm{~mm}$., retracted under the large, dark brown cervical shield. Body as before, the large flat warts pale, the ground color only showing as narrow chocolate brown dorsal and subdorsal lines, pale between the segments. Shaft of hairs segmented, the tips black, the bulb at the extreme base, small.

Stage $V$. Width of head I.I mm., as before. Warts brown in large pale gray areas which cut up the dark brown ground into straight dorsal, wavy subdorsal and broken stigmatal bands; subventral region pale brown; incisures dark, obscurely connecting the bands. Joint 2 pale in front, dark behind covering the head. Feet pale. On thorax warts $\mathrm{i}, \mathrm{ii}, \mathrm{iii}, \mathrm{iv}+\mathrm{v}$ and $\mathrm{vi}$ are present, on abdomen $\mathrm{i}+\mathrm{ii}, \mathrm{iii}, \mathrm{iv}+\mathrm{v}$, vi and leg-plate. Hairs segmented, sub-barbuled with basal bulb which shrinks to an annulus at the end of the stage. The whole color becomes dark purplish at this time.

Stage VI. Head pale brown, lighter in the sutures; width $1.6 \mathrm{~mm}$. It is retracted in the hood of joint 2, which is large with a large, dark brown, bisected cervical shield. Body thick and robust, not tapering, densely short hairy. Hairs segmented, with basal bulbs as before, well developed. Color dark velvety brown, reduced to a series of longitudinal and transverse lines by the large, rounded and slightly oblique pale gray areas which surround the upper three warts $(\mathrm{i}, \mathrm{ii}+$ iii, iv + v on thorax, i+ii, iii, iv + v on abdomen). The warts themselves are brown, forming dark centers to the pale patches, not so dark as the ground color. Hairs on lower side of third wart (iv $+v$ ) longer, concealing the subventral region. Feet pale. Spiracles brown, the one on joint 5 moved up. A circular, pale, eversible area surrounds the spiracle on joints 6 and $\mathrm{I}$.

Cocoon. This is irregular, like Harrisina but larger, the main web brownish, a little wrinkly and opaque with some white floss silk outside. Size $13 \times 6 \mathrm{~mm}$. Spun between leaves on the ground.

\section{DESCRIPTIONS OF TWO NEW FOSSORIAL WASPS.}

BY William H. ASHMEAd, WAShington, D. C.

The two new fossorial wasps described below were discovered by Prof. George W. Peckham in Wisconsin, who will shortly describe their habits and life histories.

(I) Astata leuthstromi, n. sp. \&.-Length $8 \mathrm{~mm}$. Entirely black, shining, and sparsely clothed with a whitish pubescence. Head rather closely punctate, the clypeus truncate anteriorly and fringed medially with some black hairs, on either side of which are long glittering white hairs; palpi rufo-piceous; first joint of flagellum about $\frac{1}{4}$ longer than the second, joints 2-4 subequal, about four times as long as thick. Mesonotum anteriorly finely punctate, posteriorly for at least half its length as well as the scutellum highly polished and with only a few minute scattered punctures; mesopleura punctate, closer and more distinctly so posteriorly; metathorax with a smooth impunctate space at base, confluently or regularly punctate posteriorly. Wings towards base hyaline, the apical half subfuliginous; the marginal cell is about as long as the first submarginal 

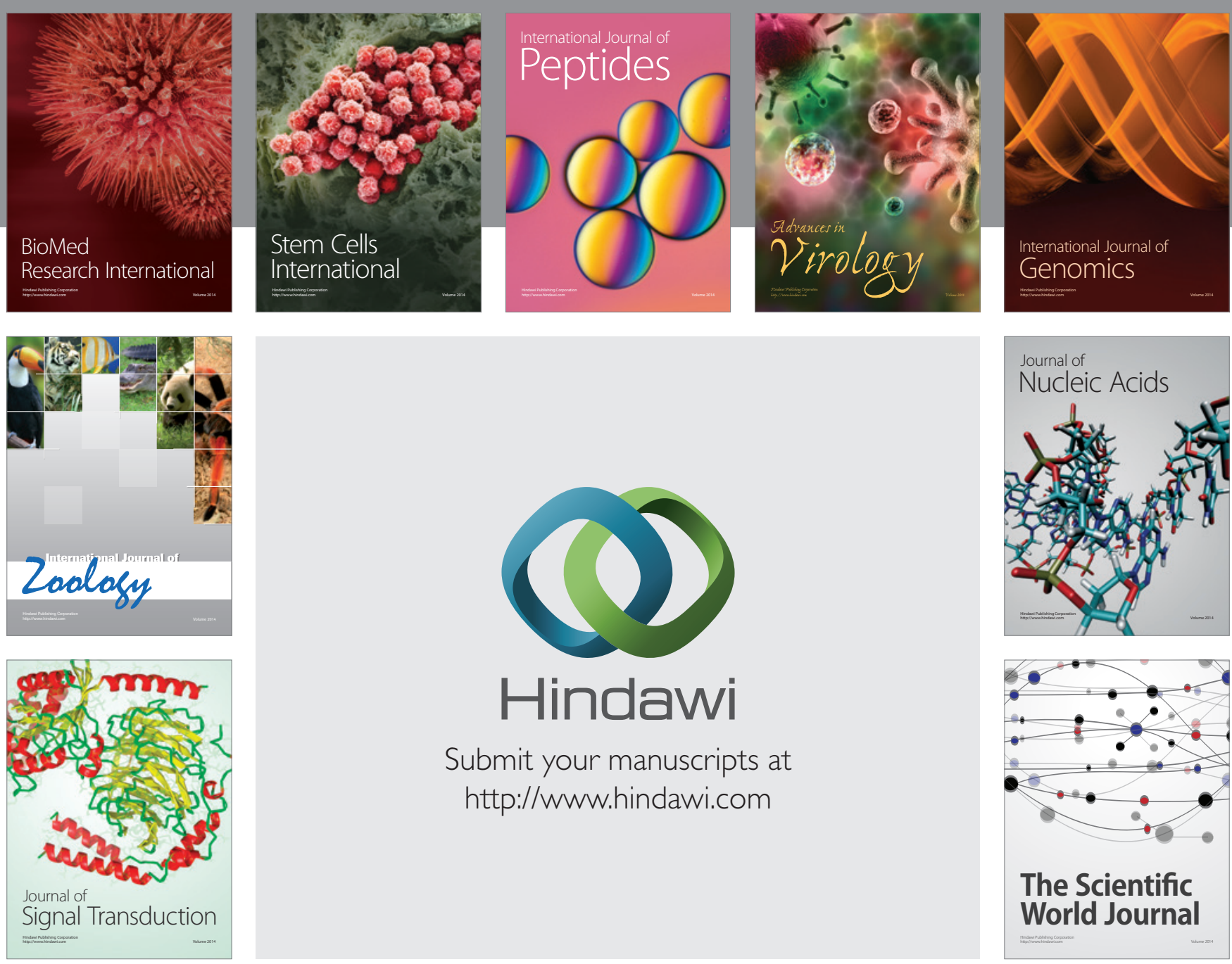

Submit your manuscripts at

http://www.hindawi.com
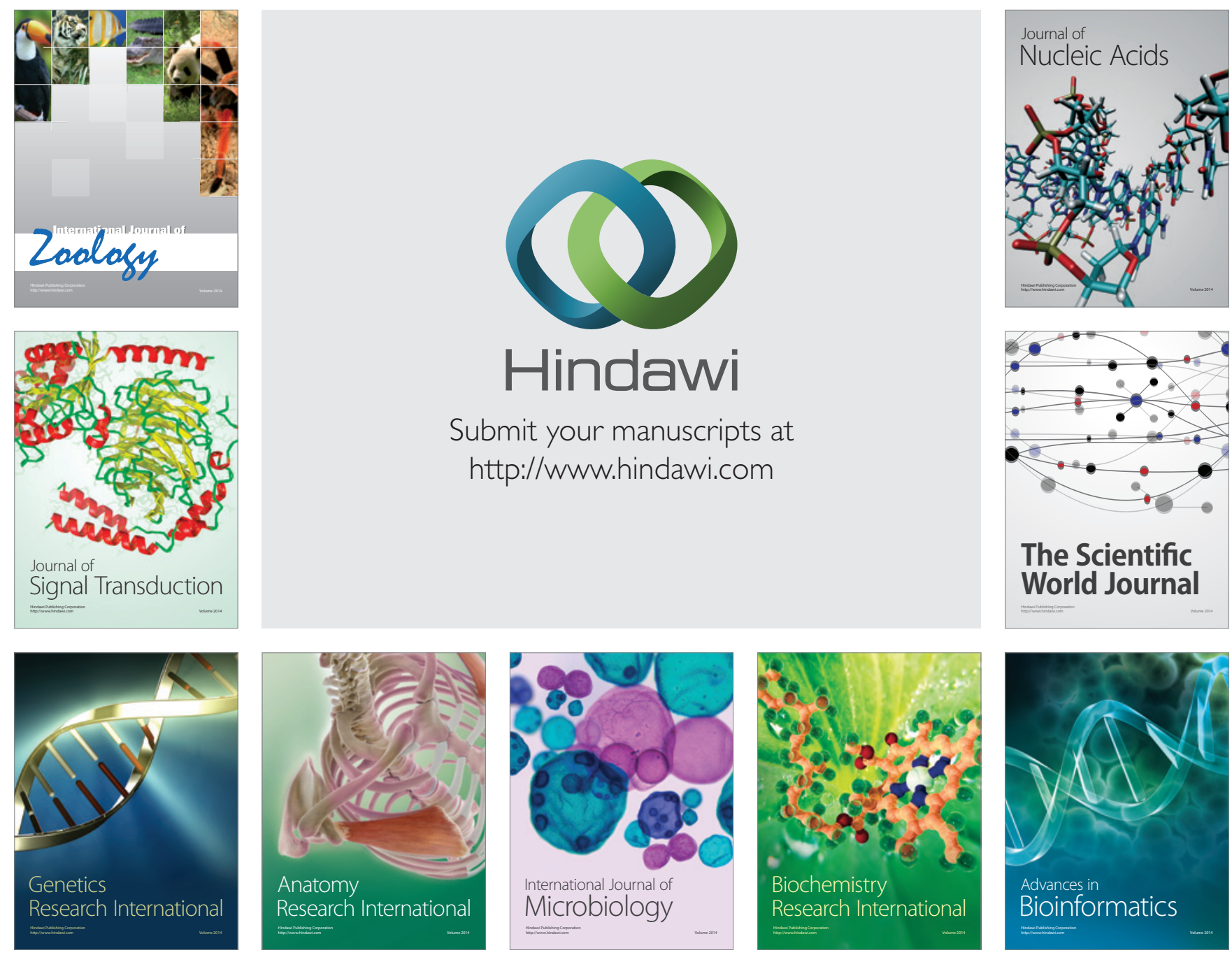

The Scientific World Journal
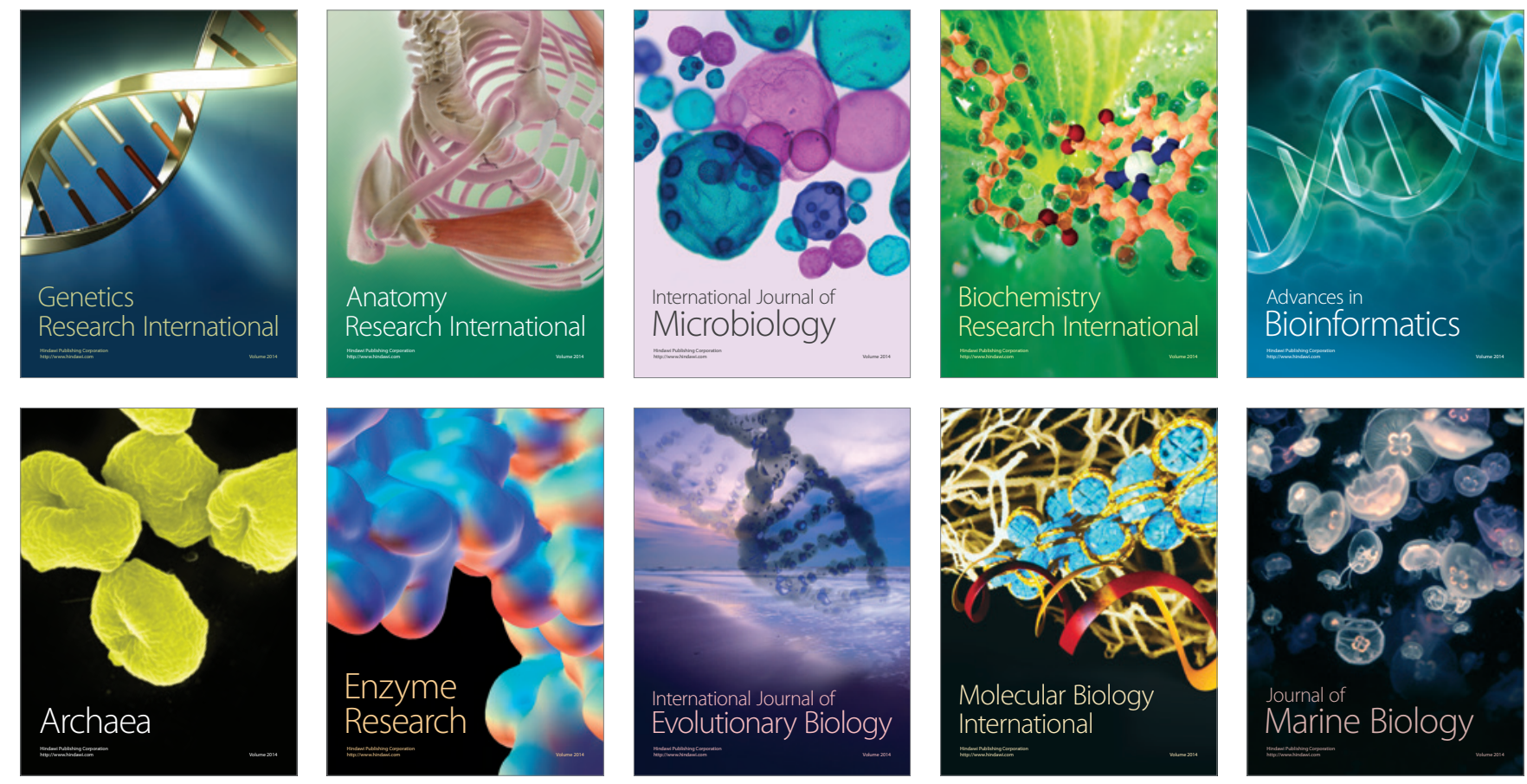